\title{
Philippines: Report on the Observance of Standards and Codes- Banking Supervision
}

This Report on the Observance of Standards and Codes on Banking Supervision* for the Philippines was prepared by the staff team of the International Monetary Fund as part of the Financial System Stability Assessment and included in the background documentation for the periodic consultation with the member country. It is based on the information available at the time it was completed on September 16, 2002. The views expressed in this document are those of the staff team and do not necessary reflect the views of the government of the Philippines or the Executive Board of the IMF.

The policy of publication of staff reports and other documents by the IMF allows for the deletion of market-sensitive information.

To assist the IMF in evaluating the publication policy, reader comments are invited and may be sent by e-mail to publicationpolicy@imf.org.

Copies of this report are available to the public from

International Monetary Fund • Publication Services

700 19th Street, N.W. • Washington, D.C. 20431

Telephone: (202) 6237430 • Telefax: (202) 6237201

E-mail: publications@imf.org • Internet: http://www.imf.org

\section{International Monetary Fund Washington, D.C.}

* Excerpt from the September 16, 2002 Financial System Stability Assessment 



\section{Summary ASSESSMEnT OF THE ObSERVANCE OF FinAnCial SECTOR STANDARDS AND CODES}

\section{INTRODUCTION AND SUMMARY}

1. This section contains summaries of the reviews of compliance and consistency with key principles and standards applicable to the financial sector. Specifically, it reviews compliance with (a) the Basel Core Principles for Effective Banking Supervision; (b) the Committee on Payment and Settlement Systems' (CPSS) Core Principles for Systemically Important Payment Systems; (d) the International Organization of Securities Commissions' (IOSCO) Objectives and Principles of Securities Regulations; (e) the International Association of Insurance Supervisors' (IAIS) Supervisory Principles; and the Code of Good Practices in Transparency in Monetary and Financial Policies. The detailed assessments for each of the standards and codes formed an integral part of the FSAP and an input into the Financial System Stability Assessment (FSSA).

2. The assessment confirms that the infrastructure for effective supervision has improved considerably in recent years and that while important gaps exist, compliance is overall quite high. The weaknesses that exist are however critical and derive in part from a supervisory structure and its enforcement capacities being out of line with key challenges. Among these are the needs to reorient the framework away from forbearance and liquidity support to on that is based on early problem identification, prompt corrective action and resolution.

3. The supervisory authorities are well aware of the concerns raised and have requested technical assistance to develop a comprehensive action plan to deal with the specific concerns as well as to ensure even higher levels of compliance with the relevant standards and codes.

4. The assessments were coordinated by Mr. Masayuki Tamagawa and prepared by:

\begin{tabular}{|l|l|}
\hline Basel Core Principles for Effective Banking Supervision & $\begin{array}{l}\text { Ms. Barbara Baldwin and Mr. Ronald McDonald } \\
\text { (Banking Supervisor, formerly Bank of England), } \\
\text { Mr. Marcel Maes (Banking Supervisor, formerly } \\
\text { Commission for Banking and Finance, Belgium) }\end{array}$ \\
\hline IAIS Core Principles on Insurance Supervision & Mr. Rodney Lester and Miguel Navarro, World Bank \\
\hline IOSCO Objectives and Principles of Securities Regulation & Mr. Noritaka Akamatsu, World Bank \\
\hline CPSS Core Principles for Systemically Important Payment Systems & $\begin{array}{l}\text { Mr. Philip Woo, (Consultant, Monetary Authority of } \\
\text { Singapore) }\end{array}$ \\
\hline Code of Good Practices on Transparency of Monetary Policy & Mr. Charles Siegman (Consultant, IMF) \\
\hline $\begin{array}{l}\text { Code of Good Practices on Transparency of Monetary and Financial } \\
\text { Policies-Banking Supervision }\end{array}$ & Mr. Charles Siegman (Consultant, IMF) \\
\hline
\end{tabular}




\begin{tabular}{|l|l|}
\hline $\begin{array}{l}\text { Code of Good Practices on Transparency of Monetary and Financial } \\
\text { Policies-Deposit Insurance }\end{array}$ & Mr. Charles Siegman (Consultant, IMF) \\
\hline $\begin{array}{l}\text { Code of Good Practices on Transparency of Monetary and Financial } \\
\text { Policies-Securities Market Supervision }\end{array}$ & Mr. Charles Siegman (Consultant, IMF) \\
\hline $\begin{array}{l}\text { Code of Good Practices on Transparency of Monetary and Financial } \\
\text { Policies-Insurance Supervision }\end{array}$ & Mr. Charles Siegman (Consultant, IMF) \\
\hline $\begin{array}{l}\text { Code of Good Practices on Transparency of Monetary and Financial } \\
\text { Policies-Payment System Oversight }\end{array}$ & Mr. Charles Siegman (Consultant, IMF) \\
\hline
\end{tabular}

\section{Compliance of Basel Core Principles for Effective Banking Supervision}

\section{A. General}

5. This assessment of the current state of the Philippines' compliance with the Basel Core Principles for Effective Banking supervision has been completed as part of the IMFWorld Bank Financial Sector Assessment Program (FSAP). Completion of a formal assessment serves several purposes. This assessment of the effectiveness of banking supervision was based on an examination of the legal framework, both generally and as specifically related to the financial sector, the self-assessment of the Core Principles, and extensive discussions with the staff of the BSP, the Philippine Deposit Insurance Corporation (PDIC), the Capital Market Development Council (CMDC), the ODG-SES, the Bankers Association of the Philippines (BAP), the external auditors and the management of commercial banks.

\section{B. General Preconditions and Macroprudential Setting}

6. The operating environment for Philippine banks has been difficult. In this context nonperforming loans (NPLs) have been increasing and profitability has been declining. Around half of the banks' NPL volume is held on a limited number of important groups and individuals and the NPL distribution pattern illustrates the existence of unacceptable concentrations in a handful of individual banks with systemic importance.

7. There have been a number of changes to the regulatory and supervisory framework. The BSP is progressively introducing supervisory approaches inspired by the Basel Committee on Banking Supervision and the best practices of the leading banks in the local market. The banking industry itself has developed, in conjunction with the BSP, a number of best practice manuals covering various topics. The Philippine accounting system is progressively evolving in the direction of international standards. On the other hand, developments in the judiciary sphere have led banks to rely more systematically on contractual arbitrage mechanisms and settlement practices outside the courts.

8. Enhanced transparency in the banking sector has been made mandatory and corporate governance has been promoted recently through a number of regulatory changes. However, 
the effective implementation of these changes will have to be closely monitored and evaluated in the future. The concentration of bank shareholding in a few shareholders, some very closely linked to business conglomerates, is an important feature of the Philippine economic fabric.. The low level of domestic savings and a poorly developed domestic corporate bond market are other structural weakness that add to the reliance of these conglomerates on bank financing.

9. A number of procedures for the resolution of problems in banks, particularly in the case of financially distressed banks, do exist but experience has shown that their application can be severely hampered by the absence of some coercive legal instruments, a certain degree of prudential forbearance and the possibility of judiciary interventions. BSP and PDIC are authorized to grant credits to banks in order to overcome temporary liquidity problems. In that event, conditions are being attached to the credits and both BSP and PDIC join efforts in monitoring the condition of the banks and searching for the best resolution mechanism.

10. According to Section 83 of the RA No. 7653, also known as the New Central Bank Act (NCBA), the BSP is also allowed to extend loans and advances to banks for a period that should not exceed 7 days without any collateral for the purpose of providing liquidity in times of need. Furthermore, Section 84 allows the BSP to extend emergency loans and advances in periods of national and/or local emergency or of imminent financial panic which directly threaten monetary and banking stability. However, these loans or advances must be secured by assets. The BSP may also grant emergency loans or advances to banks, even during normal periods for the purpose of assisting a bank in precarious condition or under serious financial pressures, provided however that the bank is not insolvent and has the required assets to secure the advances.

\section{Main Findings-Summary}

11. Objectives, autonomy, powers and resources, CP 1. Taken collectively, the central bank and banking laws and the secondary regulations provided by the supervisor constitute an appropriate legal framework. Concerns about the calibration of the business process of banking supervision and the adequacy of the BSP's human resources have to be voiced in this connection. The supervisor has recognized this and the assessment team commends the $\mathrm{BSP}$ on the efforts that have already been made to address the issue.

12. Licensing and structure, CPs 2-5. Permissible activities, the licensing process and the investment criteria are well defined (CP 2, 3, and 5). As to the ownership of banks substantial regulatory changes have to be undertaken in order to allow the supervisor to address the transfer of voting shares adequately. To that end the control test approach is preferable to a simple focusing on ownership percentages. Note that such regulations have already been drafted.

13. Prudential regulations and requirements, CPs 6-15. Although the BSP has set capital requirements for credit risks on both a solo and a consolidated basis, it has not to date 
introduced capital requirements for market risk, which is admittedly relatively insignificant at the moment, is not fully addressed either. Although large exposure limits have to be observed on a solo basis, banks are not yet required to observe them on a consolidated basis. An identical major loophole in the regulatory system affects the connected lending issue. The BSP is making efforts to introduce a consolidated supervisory approach in both areas. This particular situation draws attention to the more general issue of corporate governance that is not adequately dealt with in supervision. The BSP will have to more systematically apply qualitative standards for banks' risk management systems, including an explicit assessment of the adequacy of relevant internal policies. Existing standards on internal control should be enhanced and best practices regarding internal audit should be elaborated. The BSP requires banks to adopt some measures that prevent them becoming inadvertently involved in money laundering. The situation is expected to improve as a result of the recent enactment of an anti-money laundering law, which provides immunity for the reporting of suspicions relating to bank deposits, and the introduction in the near future of detailed implementing regulations. ${ }^{1}$ These developments will require the BSP to extend its examination procedures to monitor banks' compliance with the new regulations. The BSP is planning to formalize enhanced examination procedures in the near future and is already actively training its examiners.

14. Methods of ongoing supervision, CPs 16-20. The Philippines has just begun to conduct consolidated supervision on a comprehensive basis.. The shortcomings in consolidated reporting and analysis is a significant weakness because of the high level of connectivity in the banking system. Although BSP's supervisory framework is largely compliant with the four other CPs in this group, the current supervisory process is largely compliance based and has to be drastically reoriented towards a more risk-based approach. The BSP recognizes this and has set in train a change process to that effect, but much remains to be done. Supervisory efforts should address the necessity for banks to have in place effective systems, procedures and administrative tools to monitor and control their activities, and supervisory guidance and recommendations should be developed in these areas.

15. Accounting, CP 21. The legislation and secondary regulations that govern bank accounting represent a valid basis for the supervisory authority. However, there is evidence that all aspects are not consistently enforced, possibly leading to banks issuing financial statements that do not transparently reflect their true risk profile. Of particular concern at present is the reporting of provisioning requirements; valuation of assets, especially if sold to Asset Management Companies (AMCs) as anticipated in the near future, will need to be closely monitored. The assessment of this principle does not mitigate the concerns previously cited regarding consolidated supervision, as it focuses only on bank accounting and record keeping practices. Events in the past also lead to the conclusion that synergy with the

\footnotetext{
${ }^{1}$ The authorities have released implementing rules and regulations relating to AMLA since the mission conducted its assessment.
} 
external auditors should be enhanced and the BSP's ongoing efforts in that direction are commended.

16. Remedial measures, CP 22. The implementation periods and the required corrective actions should be significantly reviewed and enhanced. The Prompt Corrective Action framework should be strengthened to give the BSP clearer authority to implement timely enforcement actions.

17. Cross-border banking, CPs 23-25. $\mathrm{T}$ f Comprehensive and proactive information sharing and cooperation arrangements between the BSP and its international counterparts (formal and or informal) are not well developed. This in addition to the weaknesses in consolidated supervision can lead to incomplete assessments of the full group network.

\section{Recommended Action Plan}

Table 1. Recommended Action Plan to Improve Compliance of the Basel Core Principles

\begin{tabular}{|c|c|}
\hline Reference Principle & Recommended Action \\
\hline $\begin{array}{l}\text { CP 1(4) Legal Framework for Bank } \\
\text { Supervision }\end{array}$ & $\begin{array}{l}\text { R.A. } 1405 \text { on the Secrecy of Bank Deposits impedes detection of possible } \\
\text { irregularities and criminal transactions by the BSP because of the legal } \\
\text { impossibility to require bank managers to reveal the names of the deposit holders } \\
\text { except in a few limited cases. Another important shortcoming relates to the } \\
\text { difficulty of determining the liability concentration of a bank. Deposit secrecy } \\
\text { objectives can be attained through a rigorous and well-conceived confidentiality } \\
\text { system. This is the most common of the systems applied in numerous countries } \\
\text { with great success. }\end{array}$ \\
\hline CP 1(5) Legal Protection for Supervisors & $\begin{array}{l}\text { Eliminate the reference to "extraordinary diligence" in Section } 15 \text { of the NCBA } \\
\text { and make it consistent with the protections offered in the Administrative Code. }\end{array}$ \\
\hline CP 1(6) Information Sharing & $\begin{array}{l}\text { Formalize the information sharing and cooperation with other local and foreign } \\
\text { supervisory agencies through MOUs or other mechanisms. }\end{array}$ \\
\hline CP 4 Ownership & $\begin{array}{l}\text { Strengthen the ownership review process in both the licensing and change of } \\
\text { control application process to ensure that ultimate beneficial owners are properly } \\
\text { identified and the corporate structure does not hinder supervision or pose undue } \\
\text { risk to the institution. Strengthen application of Circular } 309 \text { to promptly address } \\
\text { ownership issues when they are identified; temporarily limiting the new owner's } \\
\text { role in decision-making until the problem is resolved. }\end{array}$ \\
\hline CP 9 Large Exposure Limits & $\begin{array}{l}\text { Due to the large number of financial conglomerates in the market, consolidated } \\
\text { supervision of the single-borrower limits is needed. The guidelines under } \\
\text { development by the GBL } 2000 \text { Task Force on consolidated supervision of single } \\
\text { large borrowers, connected lending and liquidity should be implemented } \\
\text { expeditiously. }\end{array}$ \\
\hline CP 11 Country Risk & $\begin{array}{l}\text { The BSP should build upon the existing examiner guidance on country risk } \\
\text { issues to develop and issue guidelines for banks on the adequacy of policies and } \\
\text { procedures for country risk. }\end{array}$ \\
\hline
\end{tabular}




\begin{tabular}{|c|c|}
\hline Reference Principle & Recommended Action \\
\hline CP 13 Other Risks & $\begin{array}{l}\text { The adaptation of existing examiner guidance and the material in the BAP } \\
\text { manual into the form of supervisory standards for banks' systems will do much } \\
\text { to ensure full compliance with this principle, and it is recommended that the task } \\
\text { should be given high priority. }\end{array}$ \\
\hline CP 14 Internal Control and Audit & $\begin{array}{l}\text { The existing Internal Control Questionnaires should be revisited in the light of the } \\
\text { results of the new best practices circular. An updating of the existing Manual of } \\
\text { Internal Control Standards for Financial Intermediaries should be undertaken. In } \\
\text { addition, the pivotal distinction between internal control and internal audit is not } \\
\text { adequately addressed, and substantive guidelines or rules of best practices } \\
\text { regarding internal audit should be elaborated by the BSP and circulated among the } \\
\text { banks. Compliance verification of the two functions should then be added to the } \\
\text { bank examiner's manual. }\end{array}$ \\
\hline CP 15 Money Laundering & $\begin{array}{l}\text { The minimum level below which there is no legal duty to report suspicious } \\
\text { transactions (PhP4 million) defeats the effectiveness of the suspicious transaction } \\
\text { reporting system and should be aligned as soon as possible with general } \\
\text { international standards. Extending the scope of examinations to include regular } \\
\text { and thorough assessments of the effectiveness of banks' anti-money laundering } \\
\text { controls, together with staff training, are also important to ensuring full } \\
\text { compliance with Principle } 15 \text {. }\end{array}$ \\
\hline CP 20 Consolidated Supervision & $\begin{array}{l}\text { Further development in both the scope and depth of the program are necessary if } \\
\text { the BSP is to effectively address the risks to banking institutions that result from } \\
\text { complex mixed-activity conglomerates operating banks. These complex } \\
\text { structures have been fuelled by tax, capital and reserve requirement incentives } \\
\text { rather than a coherent focus on the most efficient corporate structure. The tiered } \\
\text { licensing structure should be reviewed to remove such unintended incentives. In } \\
\text { addition, the BSP needs power to exercise consolidated supervision not only } \\
\text { toward downstream entities, but also upstream toward the parent company and } \\
\text { any affiliates of the parent. }\end{array}$ \\
\hline CP 22 Remedial Measures & $\begin{array}{l}\text { The BSP could strengthen the prompt corrective action program to better underpin } \\
\text { its enforcement authority. Grace periods also seem excessive; the BSP should not } \\
\text { be impeded from taking prompt action when necessary to preserve the value of a } \\
\text { troubled institution. The implementation periods and the required corrective } \\
\text { actions should be significantly reviewed and enhanced in order to achieve } \\
\text { compliance with this Core Principle. }\end{array}$ \\
\hline CP 23 Globally Consolidated Supervision & $\begin{array}{l}\text { Introduction of well-developed information sharing and cooperation agreements } \\
\text { between the BSP and its international counterparts would enhance the ability of } \\
\text { the Philippine Authorities to conduct comprehensive consolidated supervision. } \\
\text { The authorities should ensure that the requirements of RA } 1405 \text { do not impede } \\
\text { implementations of such agreements. The home country supervisor also needs to } \\
\text { assess the quality of supervision conducted in the countries in which its banks } \\
\text { have material operations. }\end{array}$ \\
\hline CP 24 Host Country Supervision & $\begin{array}{l}\text { In order to strengthen its role as host country supervisor, the BSP should } \\
\text { establish and maintain formal cooperation and information sharing agreements } \\
\text { with its foreign counterparts. It should also ensure that the home country is } \\
\text { conducting effective comprehensive consolidated supervision on the parent } \\
\text { organization on an ongoing basis. }\end{array}$ \\
\hline $\begin{array}{l}\text { CP } 25 \text { Supervision Over Foreign Banks' } \\
\text { Establishments }\end{array}$ & $\begin{array}{l}\text { A well-established program for cooperation and information sharing with home } \\
\text { country supervisors would help ensure that the BSP is capturing all relevant } \\
\text { information about the parent bank that may have a material bearing on the entity } \\
\text { operating within its borders. }\end{array}$ \\
\hline
\end{tabular}


- 7 - 